\title{
DOES MATERIAL ADVERSE CHANGE (MAC) FULL FILL THE PRINCIPLES OF AN AGREEMENT?
}

\author{
Suwinto Johan \\ President University \\ Email : suwintojohan@gmail.com \\ Markoni \\ Universitas Tarumanagara \\ Email : sh.markoni@gmail.com
}

\begin{abstract}
Material Adverse Change (MAC) clause is rarely discussed in contract law because it is an agreement between the two parties. This clause has quite extensive effects, especially at the time of the Covid-19 Pandemic. This article is generally found in company mergers and acquisitions agreements and credit or financing agreements. MAC Clause will be needed when there is a significant changes in business. This research wants to test whether the Material Adverse Change clause meets the principles' requirements in a contract or agreement. The research is normative juridical research. This research will refer to the principles in agreement and relating to the definition of Material Adverse Change/ Effect (MAC/E). This research concludes that Material Adverse Change is a clause which fulfills the principles in an agreement, especially the principle of the Freedom of Contract, the Principle of Good Balance, the Principle of Consensually (Agreement) Consensualism), the Principle of Legal Certainty (Facta Sunt Servanda), the Principle of Good Faith, and the Principle of Personality. The MAC should be effective under the Pandemic's condition.
\end{abstract}

Keywords: Contracts; Material Adverse Change; Principle; Contract

\section{INTRODUCTION}

In everyday life, we often hear the word that someone has given promises to someone else. The promise here can be connoted as something verbal. A verbal promise is also a commitment from one party to another. However, in business activities, this promise will be written rather than spoken. If the promise is written, each party's obligations and rights as part of the promise become clearer.

The rights and obligations of each party are outlined in an agreement. This engagement was written and known as an agreement. In this agreement, there is an agreement by both parties. Besides, both parties are also capable of carrying out the actions written in the agreement. The agreement must contain certain rights and obligations from one party to the other party and a clause that the action to be taken is lawful. The first two things are known as subjective conditions and lawful actions, and some things that must be done are objective conditions. 
In the normal business activities, there are many agreements, such as credit agreements between companies and banks, agreements on the execution of a project between a company and suppliers, such as building construction and completion of consultancy projects. In this agreement or contract, the intention and purpose of the contract, the transaction to be carried out, the legal provisions to be used, legal domicile, dispute resolution if any, conditions occur that can interfere with the parties to fulfill their obligations, choice of law and notification, is written in detail. The parties will affirm their respective rights and obligations, which must be fulfilled during the agreement period.

If there are parties who are unable to fulfill their obligations, which are the right that should have been received by the other parties, then the parties who have failed to fulfill these obligations must provide compensation or penalty for the other parties. However, there might be a case when there is a special event arising, which cause one of the parties to find it impossible to fulfill its obligations, not because of its failure but because there is a hindering event.

In general, an article in an agreement states that if certain conditions occur that caused the party that must fulfill their obligations to fail in fulfilling their obligations, then this condition can be tolerated, or the transaction can be canceled. This particular condition is called a force majeure condition.

However, not every condition can be categorized as a force majeure condition because not every incident will fail to fulfill one's performance. Some events delay parties to fulfill their obligations. For example, if we provide shipping services, shipping will be delayed due to extreme weather conditions. This delay is not permanent, but it has to be delayed. The condition is not yet a force majeure condition, but this condition is generally called a Material Adverse Change.

The first case of COVID-19 was first detected on March 2, 2020, when President Joko Widodo announced that 2 Indonesians had been infected at a café. Anticipatory steps have been taken along with this incident. Then, the Government issued a Government regulation on Large-Scale Social Restrictions (LSSR/PSBB) through Presidential Decree Number 11 of 2020 and Government Regulation Number 21 of 2020 on March 31, 2020.

The government of Jakarta is the first regional government to impose a Large-Scale Social Restrictions. The Government of Jakarta began to impose the Large-Scale Social Restrictions on April 10, 2020, through The Regulation of The Governor of DKI Jakarta Number 33 of 2020, after obtaining approval from the Ministry of Health. After April 12,2020 , the Government has required the use of masks for public transportation users, limiting the number of passengers and stopping activities that involve large numbers of people. 
The Indonesian Government does not consider COVID-19 as a force majeure condition. However, Large-Scale Social Restrictions policy has hampered community activities and economic activities.

If an agreement does not clear the conditions of the Pandemic, then obligations must still be fulfilled even though conditions may not be possible. If there is a force majeure article in the article, this condition cannot be used because it has not announced it yet. If the agreement states that changes, these conditions are generally written in an article called Material Adverse Change (MAC). For the MAC condition, it is generally written for the credit agreement or the company sale and purchase agreement on merger and acquisition transactions, such as a significant change in financial parameters or indicators.

MAC articles are different from Force Majeure articles. Force Majeure is more likely to be interpreted as a natural disaster, but MAC is a condition or event or shock that is temporary. The force majeure that occurs is mostly relative force majeure, so MAC is a solution to relative force majeure. MAC also could consider as an agreement between parties due to the changes of conditions (Hardship). Some examples are Black Thursday, where the major world stock price indexes experienced significant correction, and The Great Hanshin earthquake in 1995 resulted in a decline in global stock indexes. MAC is not solely a natural event, or a military or political event, such as a takeover of power or force majeure, but can be a natural event in another country with a domino effect on the capital market or financial market in Indonesia.

Other examples were the Invasion of Iraq on March 19, 2003, and the Invasion of Kuwait on August 7, 1990. The invasion resulted in instability in commodity prices, especially oil, and affected other global financial parameters such as stock indices, major commodity prices, significant world currency rates, and gold price. As a result of this change, several transactions, such as commodity shipments and gold, will experience Material Adverse Change (MAC).

Other events, such as terrorist bomb attacks and Government policies such as a moratorium, can affect transactions to be executed, such as a foreign currency moratorium. This restriction will negate the market price of a currency or value still held by the Government.

On April 20, 2020, due to COVID-19, crude oil prices experienced the worst drop with a position of minus USD 37.63 per barrel, almost all major global capital markets were pressured due to concerns about the COVID-19 Pandemic. ${ }^{1}$

Another event in Indonesia was the 2008 global financial crisis, in which Indonesia was directly affected, but the capital market and money market both the index and the IDR exchange rate in Indonesia experienced pressure.

\footnotetext{
${ }^{1}$ Idris, M,Harga Minyak Dunia Minus, BagaimanaBisa?,https://money.kompas.com/read/2020/04/21/110816026/ harga-minyak-dunia-minus accessed on 18 May 2020.
} 
The COVID-19 Pandemic, several monetary parameters in Indonesia, underwent significant changes such as the IDR exchange rate against the US Dollar, which weakened by $17.33 \%$ on April 3, 2020, compared to the beginning of March 2020 the announcement of COVID-19 in Indonesia is shown in Figure 1.

The Composite Share Price Index (CSPI) also reached 3937 on March 24, 2020, where there was a decline of more than $30 \%$ compared to March 4, 2020, is depicted in Figure 2.

Table 1 Definition of Force Majeure and Material Adverse Change

\begin{tabular}{|c|c|c|c|c|c|}
\hline No. & Clause & $\begin{array}{c}\text { Type of } \\
\text { Event }\end{array}$ & $\begin{array}{c}\text { Location of } \\
\text { Event }\end{array}$ & Determinant & Event \\
\hline 1. & Force Majeure & $\begin{array}{l}\text { Natural } \\
\text { events or } \\
\text { caused } \\
\text { by na- } \\
\text { ture }\end{array}$ & $\begin{array}{c}\text { L o c a t i o } \mathrm{n} \\
\mathrm{W} \mathrm{h} \text { e r e } \\
\text { Obligations } \\
\text { A r e } \\
\text { Performed }\end{array}$ & $\begin{array}{l}\text { Ruling Author- } \\
\text { ity }\end{array}$ & $\begin{array}{l}\text { Aceh Tsuna- } \\
\text { mi, } \\
\text { Palu Sigi } \\
\text { Donggala } \\
\text { Tsunami, } \\
\text { COVID-19 } \\
\text { Pandemic }\end{array}$ \\
\hline 2. & $\begin{array}{l}\text { Material Ad- } \\
\text { verse Change } \\
\text { (MAC) or } \\
\text { Material Ad- } \\
\text { verse Effect } \\
\text { (MAE) }\end{array}$ & $\begin{array}{l}\text { Economics } \\
\text { or finan- } \\
\text { cial or } \\
\text { military } \\
\text { or po- } \\
\text { litical } \\
\text { events }\end{array}$ & $\begin{array}{l}\text { The location } \\
\text { of the event } \\
\text { can be } \\
\text { elsewhere } \\
\text { but has an } \\
\text { impact on } \\
\text { the loca- } \\
\text { tion where } \\
\text { the obliga- } \\
\text { tions are } \\
\text { performed }\end{array}$ & $\begin{array}{c}\text { Agreement of } \\
\text { the Parties }\end{array}$ & $\begin{array}{l}\text { The } 11 \text { Sep- } \\
\text { tember } \\
\text { attack in } \\
\text { the Unit- } \\
\text { ed States, } \\
\text { terrorist } \\
\text { attack, mili- } \\
\text { tary inva- } \\
\text { sion }\end{array}$ \\
\hline
\end{tabular}

Source: Research Result

In market practice, the parties usually use this financial parameter for renegotiation due to Material Adverse Change (MAC). MAC usually occurs between the signing of the pre-condition agreement until the transaction completion. Pre-conditions agreements, for example, is Conditional Sales and Purchase Agreements (CSPA). The difference in force majeure and Material Adverse Change is illustrated in table 1.

Material Adverse Change (MAC) clauses are frequently used in merger and acquisitions and project financing contacts. MAC clauses are a common means of allocating the risks presented by adverse business or economic developments between signing and closing an acquisition agreement. ${ }^{2}$

MAC provision in credit agreements defines a MAC as a material adverse effect on (i) the business, financial condition, or results of operations of the borrowers and their subsidiaries (taken as a whole); (ii) the ability of the credit parties and their subsidiaries

${ }^{2}$ Damian, M, (2016), Investing in Infrastructure, International Best Legal Practice in Project and Construction Agreements, January

4 Jurnal IUS Kajian Hukum dan Keadilan 
(taken as a whole) to perform their payment obligations under the loan documents; or (iii) the material rights and remedies (takes as a whole) of the agent and the lenders under the loan documents. ${ }^{3}$

The MAC article in merger and acquisition transactions is generally done by canceling the agreed transaction, if the target company experiences a MAC between a specific date until the transaction completion date which is reflected in the financial statements that change such as the company's balance sheet or the company's income statement. ${ }^{4}$

One example of the event happened when Merrill Lynch was to be acquired by Bank of America. On November 3, 2008, Merrill Lynch reported a loss of \$ 5.1 billion quarterly performance in 2008. On December 3, 2008, Merrill Lynch's losses were estimated to reach $\$ 7$ billion. Then on December 14, 2008, the loss was reported to be close to $\$ 12$ billion. With this significant change, the initially agreed acquisition plan needs to be reconsidered. This event is an example of a MAC incident. ${ }^{5}$

Canceling a transaction will result in losses for both parties. Delayed transactions will also result in losses to both parties. If the object is a company, then procrastination can have a negative effect. Cancellation will also be detrimental to the stakeholders. Is the MAC a clause that does not harm the relevant parties, or does MAC meet the requirements of the principles of contracting? If there are parties who did not sign but affect due to the MAC.

Based on the explanation above, in order to achieve the principles of contracting according to article 1338 Civil Law (KUH Perdata), especially the principle of freedom of contract and the principle of balance in contracting, the authors are interested in writing this study entitled: Does the use of Material Adverse Change (MAC) meet the principles of an agreement?

This study uses empirical juridical methods, namely, by studying several contracts that occur in Indonesia and the world in connection with events associated with Material Adverse Change/Effect (MAC/MAE). This study aims to determine the parties' position and the results of the implementation of the obligations of the transactions that occur.

This research approach is in the form of a socio-legal approach, intending to want to see further effects than just a doctrinal approach to broader coverage by looking at contract law concerning the macroeconomic system, microeconomic system, and social effects associated with the position of engagement between 2 parties in a transaction.

\footnotetext{
${ }^{3}$ Weinstein, G., Wied, W., Kagan, S., Fried, F.H., (2020), Covid-19 as a Material Adverse Effect (MAC) Under M\&A and Financing Agreement, Harvard Law School Forum on Corporate Governance, April 25. https://corpgov.law. harvard.edu/2020/04/04/covid-19-as-a-material-adverse-effect-mac-under-ma-and-financing-agreements/

${ }^{4}$ Threet H.C., (2017), The Definition of Material Adverse Change: Balancing Risk in Merger Agreement Under Delaware Law. Transactions, The Tennesse Journal of Business Law, no. 18.

${ }^{5}$ Subramanian G. and Sharma N., (2012), Bank Of America - Merril Lynch, Harvard Business School. Case Study No. 9-910026
} 
This study conducted a qualitative analysis, namely analysis that aims to analyze a situation or status of phenomena with a qualitative approach or with words or sentences, group research objectives, and conclude. Conclusions are drawn inductively, namely by describing things in detail and ending with general data or facts.

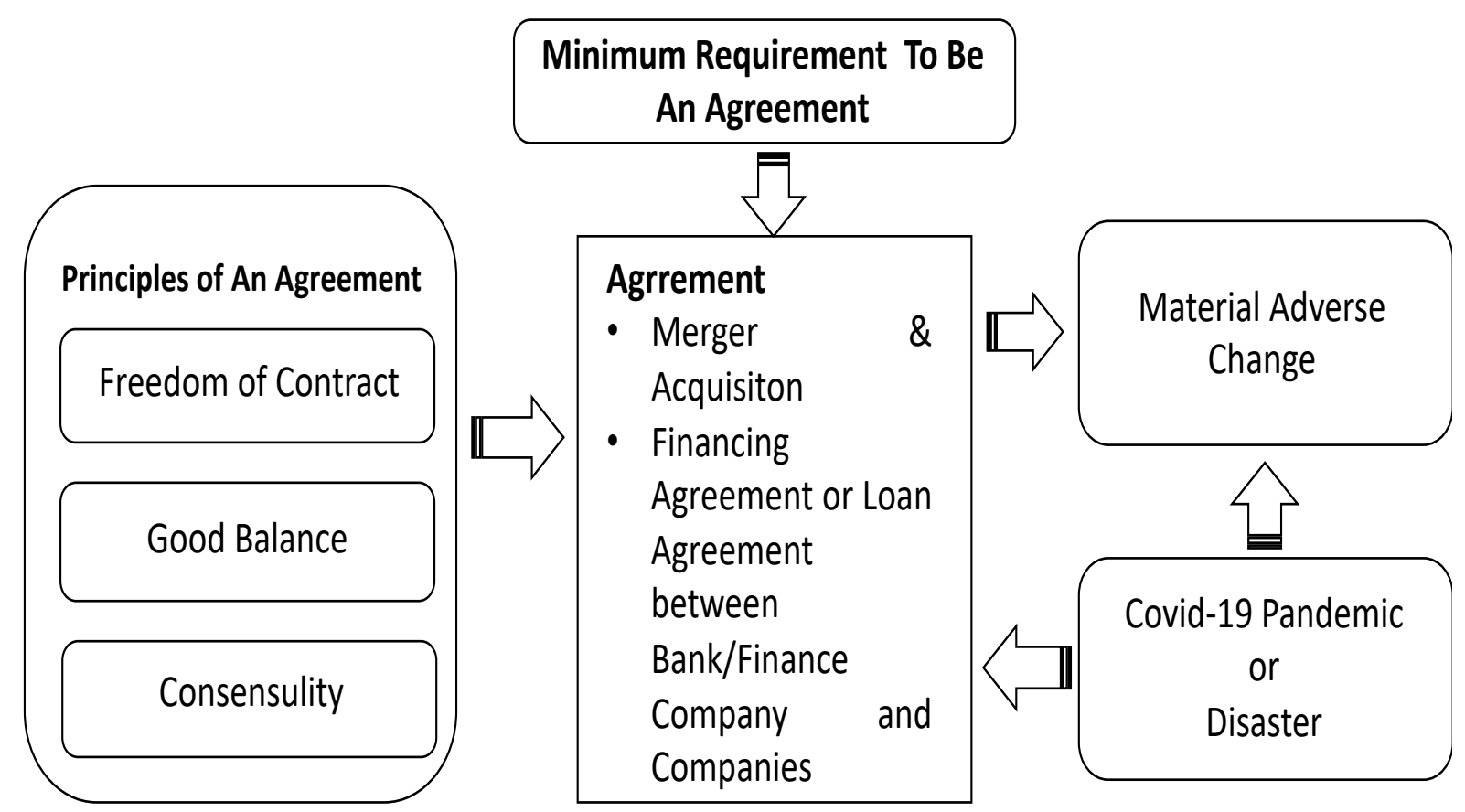

Figure 1 Research Framework

Source: research result

This study uses primary data or materials and secondary data or materials. Primary data is material or data obtained directly from the field as the primary source. At the same time, secondary material is library material in the form of primary legal materials, secondary legal materials. Data collection techniques are done by observation and interview techniques of business actors, especially in the financial services. ${ }^{6}$

In this study, it has a research framework, based on the principles of contracting, namely the principle of freedom, the principle of balance, and the principle of agreement. In addition to the three principles, a contract must also fulfill the terms of the contract.

Based on the terms and principles of contracting, the study will examine the contract or agreement relating to the agreement or contract of sale and purchase of the company and the loan agreement contract between the debtor and the banking and finance companies. This contract will be linked to the Covid-19 Pandemic that is linked to events related to Material Adverse Change (MAC).

\footnotetext{
${ }^{6}$ Lie, G., Saly, J.N., Gunadi, A., Tirayo, A.M., (2019), Problematika UU No. 37 Tahun 2004 Tentang Kepailitan dan PKPU Terhadap Bank Sebagai Kreditor Separatis, Jurnal Bakti Masyarakat Indonesia, Vol 2 No. 2. http://dx.doi. org/10.24912/jbmi.v2i2.7242
} 


\section{DISCUSSION}

\section{Agreement Theory}

Loan agreements have existed for more than 2600 years ago. Initially, loans were not in the form of cash loans, but land and building loans. Contracts for accounts receivable debt have existed since $611 \mathrm{BC}$. This contract occurred during the time of the Babylonian legal system. This contract is about binding guarantees of debt, land, and buildings as collateral for loans of money, with an interest of 11 1/3 percent per year. Loans have existed since $598 \mathrm{BC}$. This loan contract is a money loan contract (loan) with interest. Another loan contract is an unsecured money loan contract with an interest of $20 \%$ per year established in the fifth year of King Nabonidius' reign. ${ }^{7}$

Other loan agreements also appear in Hindu or Indian law in the Manu Law, where it is regulated that to be considered as a binding or valid contract, one must meet certain conditions, such as the party, when agreeing to the agreement, is not intoxicated, not mentally ill, not a minor, not a very old person, not an abnormal person, and an independent person. A contract must not be contrary to applicable laws and customs and cannot be made by force. Several things regarding the debt between the creditors and debtors are regulated in the Manu Law, including the collection process that is allowed, how to take back the loan, the amount of fines that can be imposed, if the debtor does not pay, the interest that can be charged by the creditor to the debtor, the amount of interest principal loan, how to extend debt if unable to pay at maturity and others.

In addition to the history of the law above, the history of Greek law also regulates the engagement law, including regarding loans. The practice of contract law also appeared in the history of Roman law. The contracts that appear include the deposit contract system, loan contracts, barter contracts, sale and purchase contracts, rental contracts, and contracts to do something. Roman law ranged from $275 \mathrm{BC}$ to $5 \mathrm{BC}$.

The loan treaty law also appeared in the Law of The Twelve Tables in the era of Classical Roman law. The loan agreement is in Table 3, which stipulates that people who do not pay debts may be held hostage.

In the Code of Canon Law (Corpus Iurist Canonici), a codification of Roman law and Christian teachings during the Middle Ages, there is a contract and transfer of different assets in Book V Chapter III.

\section{Terms of Agreement}

Based on article 1320 of the Civil Code, in an agreement must contain 4 legal requirements of an agreement, namely:

1. There is an agreement for those who bind themselves.

\footnotetext{
${ }^{7}$ Fuady, M. (2013), Sejarah Hukum, Ghalia Indonesia, Bogor
} 
The parties who made the agreement agreed on the principal matters agreed upon. This agreement was reached without coercion, fraud, or oversight. The agreement is considered to contain legal defects if it contains:

a. Coercion (dwang), the existence of unjust acts or threats or coercive actions

b. Fraud (bedrog) is a ruse. According to Article 1328, the Civil Code firmly states that fraud is the reason for canceling the agreement.

Whereas fraud must meet four elements, namely:
i.Action with malicious intent
ii. Made before the agreement
iii. Intending to or intending for other parties to sign agreements
iv. Actions are carried out solely with malicious intent.

2. Capability of the parties to make an agreement (om eene verbintenis aan tegaan). The article 1329 of the Civil Code states that everyone is capable of acting. Whereas 1330 Civil Code gives some exceptions to some people who are not capable of making agreements, namely:

a. Minors based on Law number 1 of 1974 Articles 47 and 50, the maturity of a person is determined that the child is under the authority of a parent or guardian until the age of 18 years. The decision of the Supreme Court Number 447/ Sip/1976 states that with the enactment of Law number 1 of 1974 , then the limit of a person under the authority of the trusteeship is 18 years, no longer 21 years.

b. Someone who is put under curatele or conservatorship. Someone who is under curatele is someone who is mentally ill, unintelligent, ill-advised, weak-minded, or also spendthrift.

c. Women in marriage (after the Supreme Court Circular Letter No. 3 of 1963 and the promulgation of Law No. 1 of 1974 Article 31 paragraph 2, women in marriage were considered to be lawful).

3. A certain issue

In an agreement, the object of the binding must be clear. Article 1333 of the Civil Code paragraph 1 states that an agreement must include the principal of an object (zaak), of which at least the type can be determined. The agreement must have an issue. The object of the agreement is not only in the form of objects, but also in the form of services. The agreement must be about a particular thing (certainty of terms), where the agreement is the rights and obligations of both parties.

4. A legal cause.

This agreement may not cover things prohibited by law or against the law, the values of politeness, or the violation of public order. For example, the sale and purchase agreement of drugs or human trafficking. This type of agreement is not allowed and does not fulfill the legal requirements of an agreement or contract. 


\section{Legal Principles of Contracting ${ }^{8}$}

A contract must fulfill several principles of contracting according to article 1338 Civil Law, namely::

\section{a. Freedom of Contract}

Both parties have agreed to enter into contracts, and both parties are capable of enteringintocontracts. Therefore, subjectiverequirementshavebeenmet. Furthermore, the contract also clearly states certain rights and fulfills just causes. In Article 1338, a freedom of contract is stated, which reads, "All treaties made legally apply as law for those who make them."

In a sale and purchase transaction, neither party is in a state of coercion or fraud by either party. The parties who sign the agreement are authorized parties who can represent individuals or institutions in acting. If it is a company, it will be represented by the directors of the company following the arrangements in the company's articles of association. The agreement is also clear about a particular object. Suppose merger and acquisition transactions, the transaction's object is a number of shares of the company being traded. The ownership of shares is also evident. This shared ownership is not in dispute with other parties. Companies whose shares are traded are not in businesses that are prohibited by law.

Both parties also agree on the contents of the agreement covering the Material Adverse Change clause.

\section{b. Principle of Balance}

The agreement made by both parties has a balanced agreement. The agreement's contents have equal rights and obligations between the seller and the buyer if the agreement is a sale and purchase of shares in the company. The seller's obligation to surrender the shares sold and the buyer's obligation to pay as well as their equal rights. Material Adverse Change arrangements must also be balanced between the two parties, buyers and sellers have the same position.

\section{c. Principle of Consensualism}

The agreement made is balanced, and both parties have a good intention in agreeing. Buying and selling of shares by buyers and sellers is an agreement that has been agreed and signed. The relevant parties have also approved the contents of the agreement. If the board of directors signs the agreement, the directors have fulfilled the requirements to sign or have obtained approval from the commissioner.

${ }^{8}$ Markoni., (2020), Bahan Kuliah Hukum Kontrak. Magister Ilmu Hukum. Fakultas Hukum Universitas Tarumanagara. 
This principle can be concluded in Article 1320, where there is an agreement between the parties who agreed. Roman Law and German Law inspired this principle.

\section{d. Principle of Legal Certainty (Facta Sunt Servanda)}

This principle explains that an agreement between two parties is a law that is made and binds both parties. This agreement is a legal source and cannot be intervened by other parties. Therefore, this agreement provides legal certainty to the parties who bind themselves in this agreement. This principle of legal certainty can be investigated more deeply in Article 1338, paragraph 1 of the Indonesian Civil Code. This principle was originally known in church law.

\section{e. Principle of Good Faith ${ }^{9}$}

The principle of good faith is in Article 1338 of the Indonesian Civil Code, which reads: The agreement must be implemented in good faith. This principle explains that the parties implement contracts or agreements based on trust or firm belief or the ability of both parties. Regarding the principle of good faith, the examples of the most prominent cases are the Sarong Parent and Mark Arrest Cases. Both of these arrests were related to the decline in the value of German currency (devaluation of German currency) after World War I. The Sarong Arrest Case: In 1918, a Dutch firm ordered German business people a number of sarong for 100,000 guilders. Due to forced circumstances, the seller can not submit orders within a specific time. After the forced situation ends, the buyer demands fulfillment. Since the agreement was made, the situation has changed a lot, and the seller is willing to fulfill the order, but at a higher price, because if the price remains the same, the seller will suffer losses. Based on good faith between the parties, the payment cannot be claimed from him.

\section{f. Principle of Personality}

This personality principle is a principle that determines that someone who will make and make a contract is only for the sake of individuals. This can be seen in Article 1315 and Article 1340 of the Indonesian Civil Code. It reads: Generally, a person cannot enter into an agreement or agreement other than himself. Article 1340 reads: The agreement only applies between the parties who made it.

\section{Form of Agreement}

The agreement can be in oral and written form. The agreement can be done with a notary deed, where this agreement includes a third party. Besides, the agreement can also be done underhandedly. Next, it can be legalized by a Notary. Waarmerking can

${ }^{9}$ Muhtarom, M. (2014), Asas-Asas Hukum Perjanjian: Suatu Landasan Dalam Pembuatan Kontrak. SUHUF Vol. 26 No. 1 pl 48-56 
also do it by the notary. The authority of notary following Law Number 30 of 2004 on Notary Position.

Legalization is where the parties have agreed, then the agreement is brought to the notary and signed in front of the notary. The notary is not responsible for the contents of the agreement. This is different from the notary deed, where the notary prepares the contents of the agreement to be made and the marking before the notary. Whereas Waarmerking, the notary only gives the stamp and registers the agreement made by the parties to the Privately-Made Letter Registration Book.

\section{Material Adverse Change (MAC)}

Material Adverse Change is a clause in an agreement, under certain conditions, that either party can cancel a signed transaction or postpone the transaction due to an event that results in that party or another party being unable to carry out his performance. This cancellation can occur between the time the initial agreement is signed, and the transaction is completed. ${ }^{10}$

The Material Adverse Change (MAC) article is mostly written in a share purchase agreement. This clause is a way for the buyer to stop the transaction, if something happens, that can affect the target company to be acquired. ${ }^{11}$

MAC's de finition is still extensive and will remain as it is for the foreseeable future. This research is conducted on merger and acquisition agreements based on the jurisdiction in the United Kingdom and the United States. MAC varies greatly between agreements. $^{12}$

The agree ment between the supplier and the consumer includes the MAC clause regarding conditions beyond the parties' control. This clause allows one party or two parties to the contract to have a reason for the delay in fulfilling their obligations if the agreement is carried out under particular conditions stated in the agreement. ${ }^{13}$

The use of MAC for buying and selling transactions is different from MAC for lending and borrowing transactions. So it is necessary to clarify the MAC criteria between the parties. An explanation of the variables is shown in table 2. Clauses that protect the acquirer have a high correlation to abnormal returns on the acquirer, and clauses that protect the target company and clauses governing competition have a high correlation to the abnormal returns of the target company. ${ }^{14}$

\footnotetext{
${ }^{10}$ Velasco E.S., (2018), Setting the boundaries between efficient and inefficient drafting practices, Master Thesis, LL.M. International Laws, Mastricht University.

${ }^{11}$ Paul P., (2016), Den Optimala MAC-kausulen I Sverige, Uppsala Universitet.

12 ibid

${ }^{13}$ Goeringer, P., Thilmany, E., and Suri, M., (2020) Force Majeure Clauses: What Are They and Do They Apply in Issues caused by COVID19? College of Agriculture \& Natural Resources Economics, University of Maryland. https:// doi.org/10.13016/eh9w-hvfg

${ }^{14}$ Coates, John C., Darius P., and Wu G., (2019), Are M\&A Contract Clauses Value Relevant to Bidder and Target Shareholders?, papaers.ssrn.com, June, https://dx.doi.org/10.2139/ssrn.3201235
} 
The quality of financial statements of companies whose acquisition targets are lower in value compared to non-target companies because the target acquisition companies do revenue management before the transaction is conducted. Besides, poor quality financial reporting has a positive correlation with the cancellation of merger and acquisition transactions. ${ }^{15}$

\section{Comparison of MAC Usage in Various Countries}

In the applicable laws of Sweden, the United States, and the United Kingdom, there is no solution to the risk of events in Material Adverse Change in contract law. Legal cases in the United States and Britain are of interest, but not in law in Sweden. In the United States and Great Britain, the courts have determined a distinct definition of MAC. The Delaware Court did not hear the MAC incident despite several cases. On that basis, to change the definition of the word MAC based on Swedish law, to avoid a relationship with the concept of contractual agreement based on Swedish law at this time.

\section{Events That Can Result in Failure to Fulfill the Obligations of an Agreement}

a. Natural Events are events caused by nature or caused by an activity from nature, such as:
a. Earthquake
b. Tsunami
c. Volcanic eruption
d. Flood
e. Tornado

\section{b. Human Events}

a. Terrorist Attack is an event in the form of a terror that can cause disruption to society and the economic system. For example, how the 2002 Bali Bombing has made Bali tourism significantly decline.

b. War is an event where there is war between one country and another. This war resulted in the inactivity of the people and the disruption of the economic system. Like the Invasion of Kuwait, the Invasion of Iraq, and several other wars.

c. Takeover of Power is a coup against the ruling Government, like a military coup against Prime Minister Thaksin in Thailand and others.

d. Change of Government, a referendum on East Timor (now Timor Leste) which resulted in a change oflawful Government and also became an independent country.

${ }^{15}$ Lim, J.H. and Chang, J.H., (2017) Earning Management of Mergers and Acquisitions of Target Candidates And Deal Withdrawan. The Journal of Applied Business Research Vol. 33 No. 3. https://doi.org/10.19030/jabr.v33i3.9937 
e. Policy of the authorities, such as Government policies on the moratorium or nationalization of foreign assets, which results in an economic system that cannot function normally.

\section{c. Pandemic Incident}

Following the definition of the World Health Organization, Pandemic is a condition where a disease has infected several countries and has fallen victim at a particular time. Some examples of Pandemics are COVID-19 Pandemic, Ebola Pandemic, AIDS Pandemic, and others.

\section{d. Significant Changes in the Economic System}

Significant changes in the economic order such as a very drastic change in interest rates, the fall of the stock index, and the occurrence of banking rush. These things can result in obstruction of a transaction involving finance. Events in the financial industry tend to have systemic risks, where events on one thing will affect other things. However, Monetary policy can affect the liquidity of small banks during normal conditions, monetary policy does not directly affect banks in financial crisis conditions, and liquidity trends will be able to predict future crises. ${ }^{16}$

\section{Material Adverse Change Fulfills the Principle of Agreements}

\section{a. Freedom of Contract Principle}

Article 1338, regarding freedom of contract, reads, "All treaties made legally apply as law for those who make them." Agreement to the article MAC, then this agreement becomes valid and binding on both parties who bind themselves to the agreement.

Therefore, the contents of the agreement covering the Material Adverse Change clause were also agreed by both parties when handled. For loan transactions, what is permitted to sign an agreement is that an individual or a person representing a legal entity already has certain conditions to fulfill the conditions of freedom of contract. The conditions include being able to act and not being in a state of accurately.

The signatory knows the conditions contained in the MAC that can be used in these conditions occur. The parties are also aware of the consequences of this MAC condition. If the conditions mentioned in the MAC Article occur in the future, the party who has agreed on the MAC conditions is the criteria.

\section{b. Principle of Balance}

The agreement made by both parties has a balanced agreement. The contents of the agreement have equal rights and obligations between the seller and the buyer.

\footnotetext{
${ }^{16}$ Berger A.N., and Bouwman H.S.C., (2017), Bank Liquidity Creation, Monetary Policy and Financial Crises, Journal of Financial Stability, Vol. 30, pg. 139-144, https://doi.org/10.1016/j.jfs.2017.05.001
} 
In determining the MAC, conditions must be stated for both parties. Unexpected events can happen to both parties. Not only those who have obligations but those who have rights. Because of the principle of balance, the MAC conditions and consequences of the MAC apply to both parties.

For example, there is a contract for shipping goods into a country, where the goods have difficulty to be sent by the seller to arrive at the destination port due to lockdown conditions. However, buyers cannot make payments because the condition is locked down and lacks funds to pay for this purchase. This is because payments from buyers are also hampered. Therefore, the principle of balance applies, not only are the sellers obstructed, but the buyer is also unable to pay. In this condition, both parties need to agree to follow up on the transaction.

The principle of balance also needs to be applied to loan transactions, which often occur are debt or creditagreements with banks and finance companies, agreements have been prepared by the standards of banks and financing companies. The customer has no choice but to sign it. The principle of the balance does occur here, but the customer does not examine the agreement.

\section{c. Principle of Consensualism}

This principle can be concluded in Article 1320, where there is an agreement between the parties who made the agreement. This principle was inspired by Roman Law and German Law. The agreement that includes the MAC article must be agreed by both parties.

\section{d. Principle of Legal Certainty (Facta Sunt Servanda)}

This principle explains that an agreement between two parties is abindinglaw made by both parties. The principle of legal certainty is found in Article 1338, paragraph 1 of the Indonesian Civil Code. This principle was originally known in church law. Agreement between the two parties is a law that binds both of them.

\section{e. Principle of Good Faith ${ }^{17}$}

The principle of good faith is in Article 1338 of the Indonesian Civil Code, which reads: The agreement must be implemented in good faith. This principle explains that the parties implement contracts or agreements based on trust or firm belief or both parties' ability.

The determination of the contents of MAC article must be in good faith and has no ulterior motive for deliberately not fulfilling obligations. The conditions in determining

${ }^{17}$ Muhtarom M. (2014) Asas-Asas Hukum Perjanjian: Suatu Landasan Dalam Pembuatan Kontrak. SUHUF, Vol. 26 No. 1 pg. $48-56$ 
the occurrence of MAC must be a condition that cannot be anticipated, and significant events are not events that can still be handled under normal conditions.

\section{f. Principle of Personality}

This personality principle is a principle that determines that someone who will make and make a contract is only for the sake of individuals. This can be seen in Article 1315 and Article 1340 of the Indonesian Civil Code, which reads: Generally, a person cannot enter into an agreement or agreement other than himself. Article 1340 reads: The agreement only applies between the party who made it.

MAC conditions made in the agreement are conditions that affect the condition rather than the wrong party. The MAC condition is not a condition that affects the condition of other parties, both directly and indirectly related to the condition of the parties related to the agreement.

Based on the above analysis, the contents of article Material Adverse Change (MAC) can be made in an agreement or contract whether it is a contract of sale, debt or other debt must meet the principles of the agreement, namely:

1. Principle of Freedom of Contract

2. Principle of Balance

3. Principle of Consensualism

4. Principle of Legal Certainty (Facta Sunt Servanda)

5. Principle of Good Faith

6. Principle of Personality

By fulfilling the agreement's principles, the contents of MAC Article fulfill the requirements of an agreement.

\section{CONCLUSION}

MAC fulfills the terms of an agreement as long as agreed by all parties in the agreement. MAC must fulfill the principles of an agreement or contract as stated in article 1338 Civil Law. The contents of the MAC clause must heed the principle of freedom of contract, the principle of agreement, the principle of legal certainty, the principle of balance, the principle of good faith, and the principle of personality, so when negotiating the matters governing the emergence of this MAC Article, these principles must be taken into consideration. MAC is also a part of the company's risk management in anticipation of events beyond its ability to control. MAC becomes part of the company's risk management. The determination of MAC for business people must pay attention to the principles in the agreement so as not to cause a dispute when the MAC is enforced. For academics, further research relating to other types of 
agreements and buying and selling companies and banking/financing loans and other exceptional conditions becomes an interesting research topic to be investigated in the future. Besides, it is necessary to include other variables besides economic and political variables in determining MAC.

\section{REFERENCES}

\section{Books}

Fuady, M. (2013), Sejarah Hukum, Ghalia Indonesia, Bogor

Markoni., (2020), Bahan Kuliah Hukum Kontrak. Magister Ilmu Hukum. Fakultas Hukum Universitas Tarumanagara.

\section{Journal and Other Scientifi References}

Berger A.N., and Bouwman H.S.C., (2017), Bank Liquidity Creation, Monetary Policy and Financial Crises, Journal of Financial Stability, Vol. 30, pg. 139-144, https:// doi.org/10.1016/j.jfs.2017.05.001

Coates, John C., Darius P., and Wu G., (2019), Are M\&A Contract Clauses Value Relevant to Bidder and Target Shareholders?, papaers.ssrn.com, June, https:// dx.doi.org/10.2139/ssrn.3201235

Damian, M, (2016), Investing in Infrastructure, International Best Legal Practice in Project and Construction Agreements, January

Goeringer, P., Thilmany, E., and Suri, M., (2020) Force Majeure Clauses: What Are They and Do They Apply in Issues caused by COVID19? College of Agriculture \& Natural Resources Economics, University of Maryland. https://doi.org/10.13016/ eh9w-hvfg

Lie, G., Saly, J.N., Gunadi, A., Tirayo, A.M., (2019), Problematika UU No. 37 Tahun 2004 Tentang Kepailitan dan PKPU Terhadap Bank Sebagai Kreditor Separatis, Jurnal Bakti Masyarakat Indonesia, Vol 2 No. 2. http://dx.doi.org/10.24912/ jbmi.v2i2.7242

Lim, J.H. and Chang, J.H., (2017) Earning Management of Mergers and Acquisitions of Target Candidates And Deal Withdrawan. The Journal of Applied Business Research Vol. 33 No. 3. https://doi.org/10.19030/jabr.v33i3.9937

Muhtarom, M. (2014), Asas-Asas Hukum Perjanjian: Suatu Landasan Dalam Pembuatan Kontrak. SUHUF Vol. 26 No. 1 pl 48-56

Paul P., (2016), Den Optimala MAC-kausulen I Sverige, Uppsala Universitet.

Subramanian G. and Sharma N., (2012), Bank Of America - Merril Lynch, Harvard Business School. Case Study No. 9-910026

Threet H.C., (2017), The Definition of Material Adverse Change: Balancing Risk in Merger Agreement Under Delaware Law. Transactions, The Tennesse Journal of Business Law, no. 18.

Velasco E.S., (2018), Setting the boundaries between efficient and inefficient drafting practices, Master Thesis, LL.M. International Laws, Mastricht University.

Weinstein, G., Wied, W., Kagan, S., Fried, F.H., (2020), Covid-19 as a Material Adverse 
Effect (MAC) Under M\&A and Financing Agreement, Harvard Law School Forum on Corporate Governance, April 25.

\section{Regulations}

Decree of Governor of DKI Jakarta Number 33 of 2020 concerning the Implementation of Large-Scale Social Restrictions in DKI Jakarta Decree of a limited cabinet meeting on the Prohibition of Going Back to Hometown

Government Regulation Number 21 of 2020 concerning Large-Scale Social Restriction

Presidential Decree Number 11 of 2020 , concerning Large-Scale Social Restriction

Presidential Decree Number 12 of 2020, concerning Non-Natural Disasters

\section{Website and Other}

Idris, M, Harga Minyak Dunia Minus, Bagaimana Bisa?, https://money.kompas.com/ $\mathrm{read} / 2020 / 04 / 21 / 110816026 /$ harga-minyak-dunia-minus accessed on 18 May 2020 . 